\begin{tabular}{ll}
\hline 原 & 著 \\
\hline
\end{tabular}

\title{
屋内のライトトラップの設置高が 八工類の捕獲数に及ぼす影響
}

\author{
木 村悟朗* \\ イカリ消毒株式会社技術研究所（干275-0024 千葉県習志野市茜浜1-12-3）
}

（受領：2020年7月1日；登載決定：2020年12月2日）

Effect of indoor light trap height on capture of Musca domestica and Megaselia scalaris

\author{
Goro KIMURA* \\ * Corresponding author: g-kimura@ikari.co.jp \\ Technical Research Laboratory, Ikari Shodoku Co. Ltd., 1-12-3 Akanehama, Narashino, Chiba 275-0024, Japan
}

(Received: 1 July 2020; Accepted: 2 December 2020)

\begin{abstract}
This study compared the number of individuals Musca domestica and Megaselia scalaris caught in multiple vertically placed traps to determine the effective placement of height of traps for monitoring. The number of $M$. domestica decreased significantly as the height of the light trap increased. The number of $M$. scalaris was largest in the highest trap when 2 or 3 traps were operated. There was no significant difference in the number of $M$. domestica and $M$. scalaris caught at different heights when only one light was turned on, which suggested that both species were attracted to the light at any height, regardless of their height preferences. These results indicate that when multiple traps are used for indoor monitoring of flies, the traps should be set at a uniform height.
\end{abstract}

Key words: monitoring, house flies, scuttle flies, distance, IPM

\section{緒 言}

建築物における衛生的環境の確保に関する法律（以下, 建 築物衛生法) において, 多数の者が使用・利用する建築物に おける有害生物の防除には, 総合的有害生物管理 (Integrated Pest Management: IPM）の理念が導入さている. 建築物衛生 法におけるIPMは有害生物の生息状況調査を重視した防除 体系である（厚生労働省, 2008). 生息状況の把握には主に トラップが用いられ, その結果に基づいて維持管理水準が設 定される. 建築物における維持管理マニュアル（以下，維持 管理マニュアル）（建築物環境衛生維持管理要領等検討委員 会，2008）におけるIPM実施モデルでは，建物内でしばしば 問題となる有害生物の調查方法や標準的な目標水準等が定め られている.

維持管理マニュアルにおいて，ハエ・コバエ類については 標準的な目標水準としてトラップによる捕獲指数が示されて いる. 一般的に, 建築物内のハエ・コバエ類の発生調査に は粘着式ライトトラップが使用され, その配置方法, 配置 期間，および捕獲指数に関する記述はあるが (平尾，2008）, 設置方法は設置場所に関することのみであり，詳細な設置条 件については記述されていない. 田中（2008）は建物内のラ イトトラップの調查において, ライトの劣化やトラップ周辺 の污損について記述しているが, 詳細な設置条件については 同様に記述していない.
ライトトラップの設置高が昆虫類の捕獲数に影響すること は屋外では古くから研究されているが (Frost, 1958), ビルや 工場などの屋内においては十分に検討されていない. 屋内 における昆虫類を対象としたライトトラップの設置高とし て, 床面から 1.5 1.8 m（川上，杉山，2009）や2.0〜2.5 m 程 度（谷川ら，2007）などがあるが，その根拠は不明であり， 屋内のハエ・コバエ類を対象とした詳細な設置高の条件は報 告されていない. また, 具体的な設置高は示されていない が, ライトトラップの設置高はそれらのライトの交換や捕虫 紙の交換などのメンテナンス性や衝突やそれに伴う破損を避 けるための安全性への配慮を指摘するものもある（尾野ら, 2016）。一方，八工類を捕殺（物理的防除）する目的で電撃 殺虫機を使用する場合, できるだけ床に近い, 低い位置に設 置するとよいといわれているが（三井，1990）, 屋内におけ る電撃殺虫機は電気設備技術基準解釈第2 26 条によって, 屋 内にあっては床上 $1.8 \mathrm{~m}$ 以上と定められており, 設置高には 制限がある.

本研究は, 屋内におけるハエ・コバエ類の生息調查で用い られるライトトラップの設置高が捕獲数に及ぼす影響を明ら かにし, 設置高の根拠を示すために, しばしば室内で問題に なり, かつ試験に十分な個体数が使用可能である種として, 八工類はイエバエMusca domestica Linnaeus, コバエ類はクサ ビノミバエMegaselia scalaris（Loew）(以下，ノミバエ）を用 いて, 垂直方向に複数台設置したライトトラップに捕獲され 
る個体数を比較した.

\section{材料と方法}

\section{供試虫}

イエバエ（2014年に福島県で採集された個体群）とノミバ エ（2012年に住化テクノサービス株式会社から購入した個 体群）は $25^{\circ} \mathrm{C}, 60 \% \mathrm{RH}, \mathrm{L}: \mathrm{D}=14: 10$ の条件下で飼育した。イ エバエ成虫は蝿飼育箱に入れ，砂糖，粉ミルク，および水を 与えた。 ノミバエ成虫はプラスチックカップに入れナイロン ゴースで蓋をして，水を与えた。いずれも雌雄混合で飼育し た。イエバエでは羽化後日齢が進むほど，また室内への放 虫数が多いほど, 部屋 $\left(34.0 \mathrm{~m}^{2}\right)$ の白壁に設置したライトト ラップでの捕獲率が減少することが報告されている（Snell, 2002)。本試験では, 捕獲率減少の影響が小さい条件の組み 合わせとして, 羽化後 1 週間以内のイエバエを各試験で 100 個体ずつ使用し，ノミバエはイエバエの条件に合わせて実験 を行った。

\section{試験 1：ライトトラップ設置高の影響}

ライトトラップの高さの選好性は，等間隔で設置されたラ イトトラップを用いて評価した。試験はイカリ消毒株式会社 技術研究所内の放虫室（幅 $\times$ 奥行 $\times$ 高さ $=4.0 \mathrm{~m} \times 4.0 \mathrm{~m} \times 2.7 \mathrm{~m}$ $\left[43.2 \mathrm{~m}^{3}\right]$, エアタイトドア，吸排気とエアコンはナイロン ゴースで覆い，不要なコンセントもテープで塞ぎ，昆虫の逃 亡を防止した．空はない）で行った．20ワットのブラック

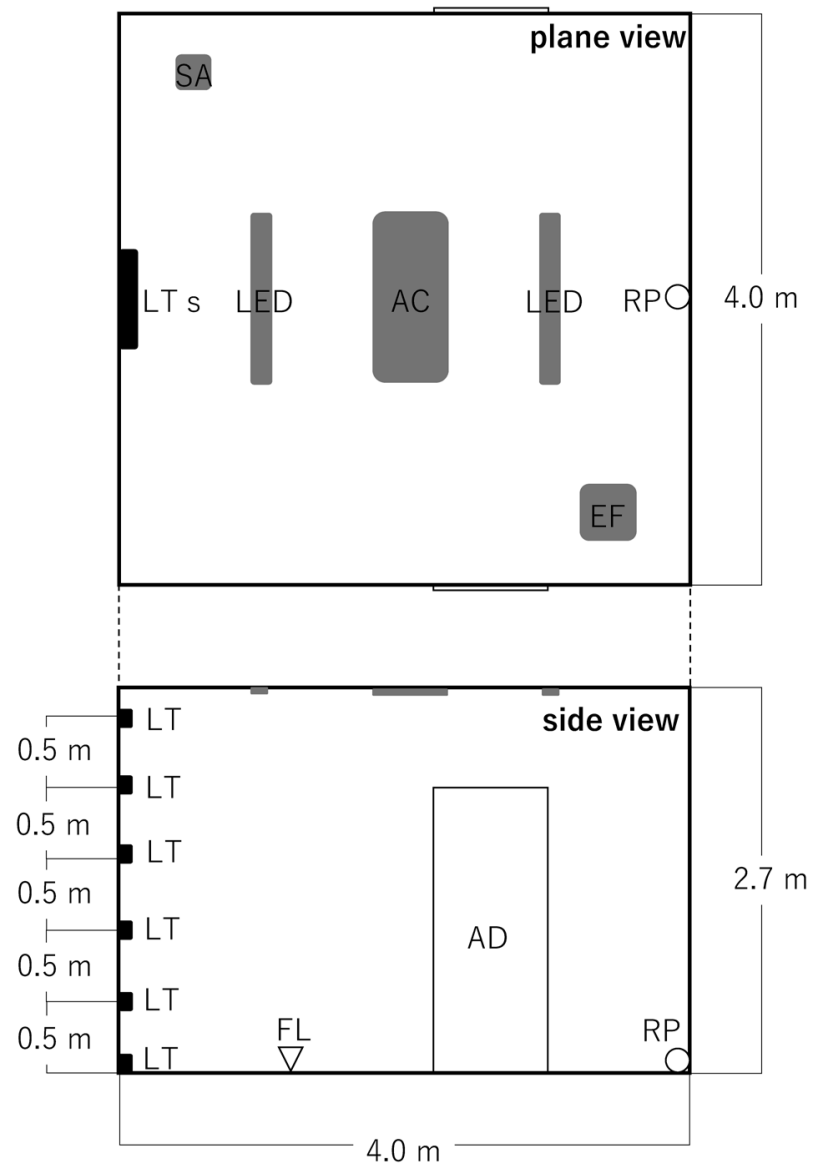

AC: air conditioner, AD: airtight door, EF: exhaust fan, FL: floor level, LT: light traps, RP: release point, SA: supply air.

Fig. 1. Layout of light traps placed in room.
ライト（蛍光管）を1本付設した粘着式ライトトラップ（オ プトクリン 7 , イカリ消毒株式会社. 以下, ライトトラッ プ）の設置高はこれまでの報告（谷川ら，2007; 川上，杉 山，2009）を参考に $0.5 \mathrm{~m}$ 間隔として，放虫室の壁中央に高 さ $0 \mathrm{~m}$ (床), $0.5 \mathrm{~m}, 1.0 \mathrm{~m}, 1.5 \mathrm{~m}, 2.0 \mathrm{~m}$, および $2.5 \mathrm{~m}$ に配置し た (Fig. 1).コバ工類は床下の配水管内の堆積物や, 配水管 からの漏水が原因となる污泥から発生することがあるため, 放虫はライトトラップを設置した対面（距離は部屋の最大值 である $4.0 \mathrm{~m}$ ）の床面からイエバエとノミバエをそれぞれ 100 個体（雌雄は区別しない），別々に放虫した，放虫 24 時間後 に各ライトトラップで捕獲されたイエバエとノミバエの個体 数を計数した。 なお，本試験で使用した放虫室にイエバエも しくはノミバエを 100 個体放虫した場合，いずれも放虫後 12 時間以降は捕獲数がほとんど増加しないことを予備実験の結 果から把握している (未発表)。試験は 3 回反復した。試験

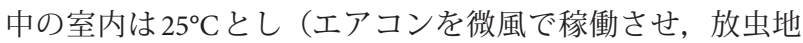
点と各ライトトラップ正面において熱線式風速計 [testo 405$\mathrm{V} 1$, 株式会社テストー] で測定した風速は $0.1 \mathrm{~m} / \mathrm{s}$ 未満であっ た), 建物の利用者が集中する時間帯および常に稼動して いるビルや工場を想定し，全明条件（LEDベースライト 40 形XLX430NENCLA9，パナソニック株式会社，21.5 ワット， 2本）とした. 物理量に基づいた光の単位はいくつかあるが, 白色LEDは紫外線を放射しないことから，ライトトラップ から放射される光の単位として紫外線強度を測定した．各ラ イトトラップの正面（ライトトラップを設置した壁の対面 の壁の0〜2.5 mの高さ）から紫外線強度計（UVA-365, 株式 会社カスタム）のセンサーをトラップを設置した壁の方向 に向けて紫外線強度を 10 秒間測定し，その最大・最小值を 記録した. なお, 紫外線強度計のセンサー部を各ライトト ラップに取り付けたブラックライトに密着させて測定した紫 外線強度は $0 \mathrm{m:}: 3.71 \sim 3.72 \mathrm{~mW} / \mathrm{cm}^{2}, 0.5 \mathrm{~m}: 3.74 \sim 3.74 \mathrm{~mW} / \mathrm{cm}^{2}$, $1.0 \mathrm{~m}: 3.71 \sim 3.71 \mathrm{~mW} / \mathrm{cm}^{2}, 1.5 \mathrm{~m}: 3.70 \sim 3.70 \mathrm{~mW} / \mathrm{cm}^{2}, 2.0 \mathrm{~m}$ : $3.72 \sim 3.72 \mathrm{~mW} / \mathrm{cm}^{2}, 2.5 \mathrm{~m}: 3.74 \sim 3.77 \mathrm{~mW} / \mathrm{cm}^{2}$ であった.

\section{試験 2：ライトトラップ消灯の影響}

試験 1 で床から天井まで等間隔に点灯していたライトト ラップの点灯範囲を縮小した場合の高さの選好性の変化を調 ベるために, 試験 1 と同じ放虫方法で, ライトトラップを床 面から順に消灯させた場合の各トラップに捕獲された個体数 を計数した. 加えて, 高さ $0 \mathrm{~m}$ の, および高さ $1.5 \mathrm{~m}$ の 点灯させた場合の捕獲個体数についてもあわせて試験を行つ た. 点灯しているライトトラップで放虫したハエ・コバエ類 を捕獲するために, これらの試験で消灯しているライトト ラップには粘着紙を装着しなかった. 各点灯条件における放 虫地点の紫外線強度は試験 1 と同様に測定した（消灯してい るライトトラップを含む). 各ライトトラップの点灯／消灯 の条件において, 3 回ずつ試験を反復した.

\section{統計的解析}

点灯するライトトラップの高さと各設置高におけるイエバ エとノミバエの捕獲数との関係を解析した．また，点灯する ライトトラップの高さと各設置高におけるイエバエとノミバ エの捕獲数の違いについては, 群間で全ての対比較を検定し た. 加えて, 各設置高の紫外線強度 (最大值) とイエバエと ノミバエの平均捕獲数との関係も解析した. すべての統計的 
解析はSPSS（Ver. 11.5.1 J, SPSS Japan Inc）を用いた.

\section{結果}

試験 1：ライトトラップ設置高の影響

イエバエとノミバエの全ライトトラップで捕獲された平均 総捕獲数（土標準偏差）はそれぞれ $83.7 \pm 4.5$ 個体と $68.7 \pm 1.5$ 個体であった。

イエバエに打ける各ライトトラップの平均捕獲数は, 高 さ $0 \mathrm{~m}$ が $34.7 \pm 4.5$ 個体で最も多く, 次いで $0.5 \mathrm{~m} て ゙ 21.0 \pm 1.0$ 個体, $1.0 \mathrm{~m}$ で $15.0 \pm 2.0$ 個体であった. イエバエの捕獲数は ライトトラップの位置が高くなるにつれて有意に減少した $(n=18, r=-0.935, p<0.001$, Pearsonの相関係数）（Fig. 2).

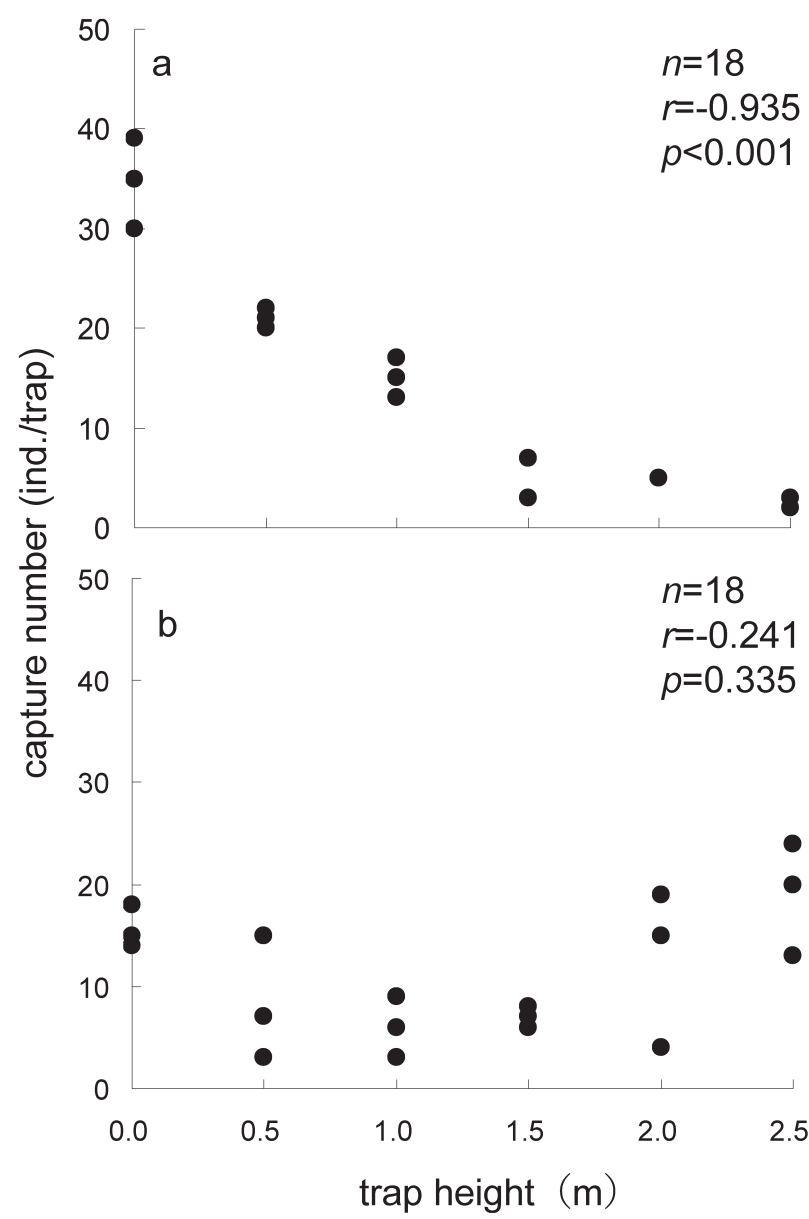

Fig. 2. Relationship between trap height and capture number with all light traps turned on a) Musca domestica; b) Megaselia scalaris.
一方，ノミバエに扔ける各ライトトラップの平均捕獲数 は, 高さ $2.5 \mathrm{~m}$ が $19.0 \pm 5.6$ 個体で最も多く, 次いで $0 \mathrm{~m} て ゙ 15.7$ \pm 2.1 個体, $2.0 \mathrm{~m}$ で $12.7 \pm 7.8$ 個体であった. ノミバエの捕獲 数とライトトラップの高さとの間に有意な相関はなかった （ $n=18, r=0.241, p=0.335$, Pearsonの相関係数）（Fig. 2).

全ライトトラップが点灯している状態において, 紫外線 強度は $0.5 \mathrm{~m}$ で最大值 $17.9 \sim 18.0 \mu \mathrm{W} / \mathrm{cm}^{2}$ に達し, 次いで $1.0 \mathrm{~m}$ で $17.3 \sim 17.5 \mu \mathrm{W} / \mathrm{cm}^{2}, 0.0 \mathrm{~m}$ で $16.5 \sim 16.8 \mu \mathrm{W} / \mathrm{cm}^{2}$ あった（Table 1). $0.5 \mathrm{~m}$ 以上では, 測定位置が高くなるにつれて紫外線強 度は減少したが, 各高さのイエバエまたはノミバエの平均捕 獲数と紫外線強度（最大值）との間には有意な相関関係はな かった（イエバエ： $n=6, r=0.618, p=0.191$ ，ノミバエ: $n=6$, $r=-0.780, p=0.067$, Pearsonの相関係数).

\section{試験2：ライトトラップ消灯の影響}

ライトトラップを下から順に消灯させると，イエバエは常 に最も下に位置するライトトラップに最大の捕獲数が得られ た (Fig. 3). 全て点灯している場合, $0 \mathrm{~m}$ の捕獲数は $0.5 \mathrm{~m}$ 以 上よりも有意に多く, $0.5 \mathrm{~m}$ は $1.5 \mathrm{~m}$ 以上よりも有意に多く, $1.0 \mathrm{~m}$ は $1.5 \mathrm{~m}$ 以上よりも有意に多く, $1.5 \mathrm{~m}$ 以上ではそれより も高いトラップとの間に有意な差は認められなかった（Fig. 3, TukeyのHSD 検定)。 $0 \mathrm{~m}$ を消灯させた場合， $0.5 \mathrm{~m}$ の捕獲 数は $1.0 \mathrm{~m}$ 以上よりも有意に多く, $1.0 \mathrm{~m}$ は $2.0 \mathrm{~m}$ 以上よりも 有意に多く, $1.5 \mathrm{~m}$ 以上ではそれよりも高いトラップとの間 に有意な差は認められなかった（Fig. 3, TukeyのHSD 検定). $0 \mathrm{~m}$ と $0.5 \mathrm{~m}$ を消灯した場合, $1.0 \mathrm{~m}$ の捕獲数は $1.5 \mathrm{~m}$ 以上よ りも有意に多く, $1.5 \mathrm{~m}$ 以上ではそれよりも高いトラップと の間に有意な差は認められなかった（Fig. 3, Tukeyの HSD 検 定). $0 \mathrm{~m}, 0.5 \mathrm{~m}$ ，および $1.0 \mathrm{~m}$ を消灯した場合， $1.5 \mathrm{~m}$ の捕獲 数は $2.0 \mathrm{~m}$ 以上よりも有意に多く, $2.0 \mathrm{~m}$ は $2.5 \mathrm{~m} よ り も$ 有意 に多かった (Fig. 3, TukeyのHSD検定). $0 \mathrm{~m}, 0.5 \mathrm{~m}, 1.0 \mathrm{~m}$ ，お よび $1.5 \mathrm{~m}$ 消灯した場合, $2.0 \mathrm{~m}$ は $2.5 \mathrm{~m}$ よりも有意に多 かった (Fig. 3,t検定)。一方， $0 \mathrm{~m}, 1.5 \mathrm{~m}$ ，または $2.5 \mathrm{~m}$ のを 点灯した場合のみで比較すると, それぞれの捕獲数には有意 な差は認められなかった（TukeyのHSD検定）.

一方，ノミバエはライトトラップを $0.5 \mathrm{~m}$ まで消灯させた 場合，捕獲数に有意な差は認められなかったが， $1 \mathrm{~m}$ までの 消灯と $1.5 \mathrm{~m}$ までの消灯では $2.5 \mathrm{~m}$ のラップで有意に多くの 個体が捕獲された（Fig. 4). 全て点灯, $0 \mathrm{~m}$, および $0 \mathrm{~m}$ と $0.5 \mathrm{~m}$ を消灯させた場合, 各高さの捕獲数に有意な差は認め られなかった（Fig. 4, TukeyのHSD検定)。 $0 \mathrm{~m}, 0.5 \mathrm{~m}$ ，および $1.0 \mathrm{~m}$ を消灯した場合, $1.5 \mathrm{~m}$ と $2.0 \mathrm{~m}$ との捕獲数に有意な差

Table 1. Variation in UV intensity for each lighting status.

\begin{tabular}{|c|c|c|c|c|c|c|c|c|c|c|c|c|c|c|c|c|}
\hline \multirow{2}{*}{$\begin{array}{l}\text { light } \\
\text { trap } \\
\text { height } \\
(\mathrm{m})\end{array}$} & \multicolumn{2}{|c|}{ On: $0-2.5 \mathrm{~m}$} & \multicolumn{2}{|c|}{ On: $0.5-2.5 \mathrm{~m}$} & \multicolumn{2}{|c|}{ On: $1.0-2.5 \mathrm{~m}$} & \multicolumn{2}{|c|}{ On: $1.5-2.5 \mathrm{~m}$} & \multicolumn{2}{|c|}{ On: $2.0-2.5 \mathrm{~m}$} & \multicolumn{2}{|c|}{ On: $0 \mathrm{~m}$} & \multicolumn{2}{|c|}{ On: $1.5 \mathrm{~m}$} & \multicolumn{2}{|c|}{ On: $2.5 \mathrm{~m}$} \\
\hline & $\begin{array}{l}\min . \\
(\mu \mathrm{W} / \\
\left.\mathrm{cm}^{2}\right)\end{array}$ & $\begin{array}{l}\max . \\
(\mu \mathrm{W} / \\
\left.\mathrm{cm}^{2}\right)\end{array}$ & $\begin{array}{l}\text { min. } \\
(\mu \mathrm{W} / \\
\left.\mathrm{cm}^{2}\right)\end{array}$ & $\begin{array}{l}\max . \\
(\mu \mathrm{W} / \\
\left.\mathrm{cm}^{2}\right)\end{array}$ & $\begin{array}{l}\text { min. } \\
(\mu \mathrm{W} / \\
\left.\mathrm{cm}^{2}\right)\end{array}$ & $\begin{array}{l}\max . \\
(\mu \mathrm{W} / \\
\left.\mathrm{cm}^{2}\right)\end{array}$ & $\begin{array}{l}\text { min. } \\
(\mu \mathrm{W} / \\
\left.\mathrm{cm}^{2}\right)\end{array}$ & $\begin{array}{l}\max . \\
(\mu \mathrm{W} / \\
\left.\mathrm{cm}^{2}\right)\end{array}$ & $\begin{array}{l}\min . \\
(\mu \mathrm{W} / \\
\left.\mathrm{cm}^{2}\right)\end{array}$ & $\begin{array}{l}\max . \\
(\mu \mathrm{W} / \\
\left.\mathrm{cm}^{2}\right)\end{array}$ & $\begin{array}{l}\text { min. } \\
(\mu \mathrm{W} / \\
\left.\mathrm{cm}^{2}\right)\end{array}$ & $\begin{array}{l}\max . \\
(\mu \mathrm{W} / \\
\left.\mathrm{cm}^{2}\right)\end{array}$ & $\begin{array}{l}\text { min. } \\
(\mu \mathrm{W} / \\
\left.\mathrm{cm}^{2}\right)\end{array}$ & $\begin{array}{l}\max . \\
(\mu \mathrm{W} / \\
\left.\mathrm{cm}^{2}\right)\end{array}$ & $\begin{array}{l}\text { min. } \\
(\mu \mathrm{W} / \\
\left.\mathrm{cm}^{2}\right)\end{array}$ & $\begin{array}{l}\max . \\
(\mu \mathrm{W} / \\
\left.\mathrm{cm}^{2}\right)\end{array}$ \\
\hline 0 & 16 & 1 & & 13 & & & & & & 3. & 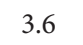 & 3. & & & 1. & 1.3 \\
\hline 0.5 & 17.9 & 18.0 & 13.7 & 13.8 & 11.2 & 11.3 & 6.7 & 6.8 & 4.3 & 4.3 & 3.2 & 3.2 & 2.5 & 2.5 & 1.8 & 1.9 \\
\hline 1.0 & 17.3 & 17.5 & 14.3 & 14.5 & 11.6 & 11.6 & 6.7 & 6. & 3.1 & 5. & 2.8 & 2. & 2.6 & 2.6 & 2.1 & 2.2 \\
\hline 1.5 & 16.2 & 16.5 & 14.0 & 14.2 & 11.6 & 11.9 & 8.7 & 8. & 5.8 & 5.9 & 1.7 & 1.7 & 2.8 & 2.8 & 2.6 & 2.6 \\
\hline 2.0 & 14.7 & 15.0 & 13.2 & 13.4 & 11.6 & 11.7 & 9.4 & 9.4 & 6.6 & 6.6 & 0.8 & 0.8 & 2.5 & 2.5 & 3.2 & 3.2 \\
\hline 2.5 & 12.0 & 12.2 & 11.3 & 11.5 & 10.9 & 10.9 & 8.6 & 8.7 & 6.7 & 6.8 & 0.3 & 0.3 & 1.9 & 1.9 & 3.3 & 3.3 \\
\hline
\end{tabular}




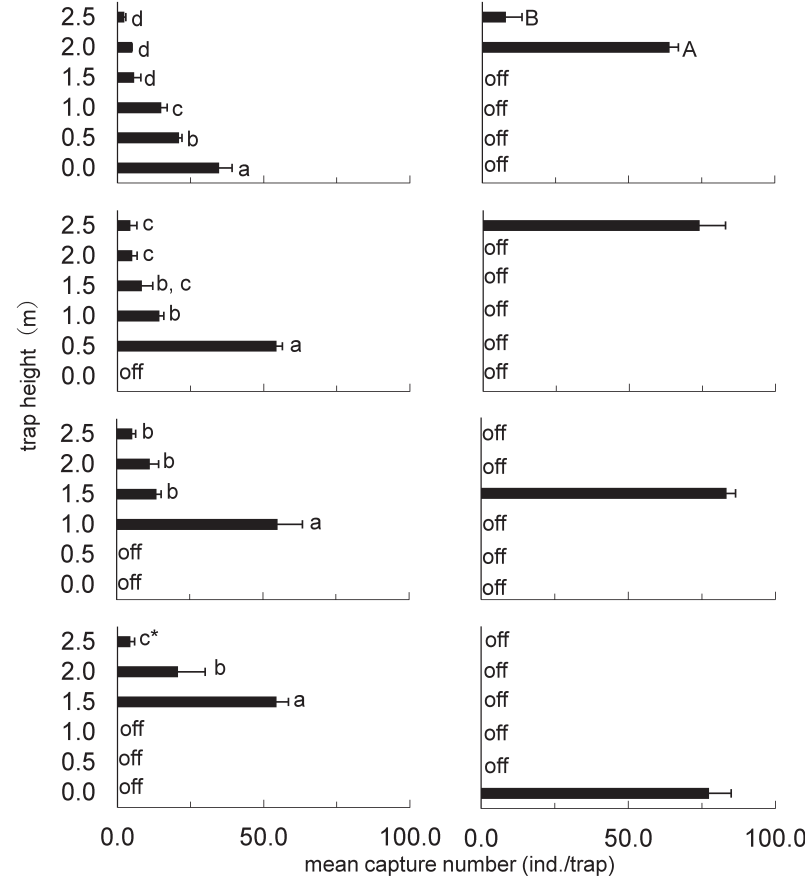

Fig. 3. Effects of the number and the height of light traps on the number of Musca domestica captured. Data are presented as mean \pm S.D. Lower case letters indicate significant differences from each test using Tukey HSD, $p<0.01\left({ }^{*} p<0.05\right)$. Upper case letters indicate significant difference using student's $t$-test, $p<0.01$. The difference between groups with same labels are not significant.

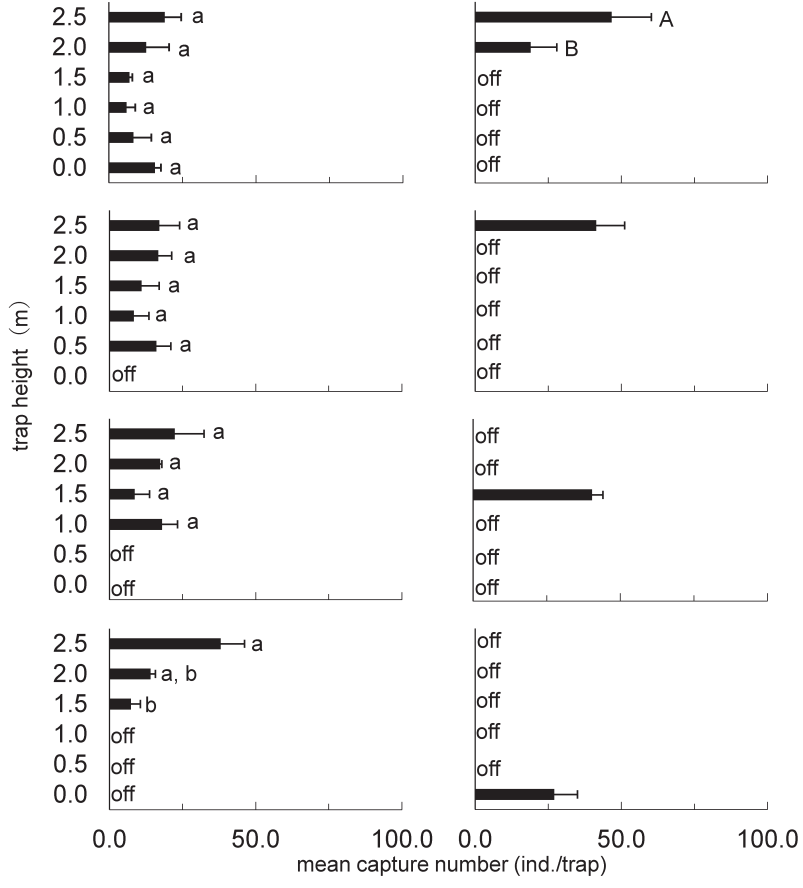

Fig. 4. Effects of the number and the height of light traps on the number of Megaselia scalaris captured. Data are presented as mean \pm S.D. Lower case letters indicate significant differences from each test using Tukey HSD, $p<0.01$. Upper case letters indicate significant difference using student's $t$-test, $p<0.05$. The difference between groups with same labels are not significant.

Table 2. Comparison of total number of Musca domestica and Megaselia scalaris for each lighting status. Data are presented as mean \pm S.D. Lower case letters indicate significant differences from each test using Tukey HSD. The difference between treatments within species with same leiter are not significant.

\begin{tabular}{ccccccccc}
\hline \hline & On: $0-2.5 \mathrm{~m}$ & On: $0.5-2.5 \mathrm{~m}$ & On: $1.0-2.5 \mathrm{~m}$ & On: $1.5-2.5 \mathrm{~m}$ & On: $2.0-2.5 \mathrm{~m}$ & On: $0 \mathrm{~m}$ & On: $1.5 \mathrm{~m}$ & On: $2.5 \mathrm{~m}$ \\
\hline $\begin{array}{c}\text { Musca } \\
\text { domestica }\end{array}$ & $83.7 \pm 4.5^{\mathrm{a}}$ & $86.3 \pm 4.7^{\mathrm{a}}$ & $85.3 \pm 5.5^{\mathrm{a}}$ & $79.3 \pm 5.1^{\mathrm{a}}$ & $72.0 \pm 2.6^{\mathrm{a}}$ & $77.3 \pm 7.6^{\mathrm{a}}$ & $83.3 \pm 3.1^{\mathrm{a}}$ & $74.0 \pm 8.9^{\mathrm{a}}$ \\
$\begin{array}{c}\text { Megaselia } \\
\text { scalaris }\end{array}$ & $68.7 \pm 1.5^{\mathrm{a}}$ & $69.0 \pm 10^{\mathrm{a}}$ & $66.3 \pm 4.9^{\mathrm{a}}$ & $59.3 \pm 12.1^{\mathrm{a}} \mathrm{b}$ & $65.7 \pm 8.1^{\mathrm{a}}$ & $27.0 \pm 7.9^{\mathrm{c}}$ & $40.3 \pm 3.8^{\mathrm{b}}$ & $41.3 \pm 9.8^{\mathrm{b}}$ \\
\hline
\end{tabular}

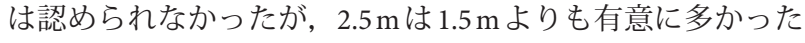
(Fig. 4, Tukeyの HSD 検定). $0 \mathrm{~m}, 0.5 \mathrm{~m}, 1.0 \mathrm{~m}$ ，および $1.5 \mathrm{~m}$ を 消灯した場合， $2.5 \mathrm{~m}$ は $2.0 \mathrm{~m} よ り も$ 有意に多かった（Fig. $4, \mathrm{t}$ 検定)。一方， $0 \mathrm{~m}, 1.5 \mathrm{~m}$ ，または $2.5 \mathrm{~m}$ のみ点灯した場合の みで比較すると, それぞれの捕獲数には有意な差は認められ なかった（TukeyのHSD検定）.

消灯に伴って紫外線強度も減少したが (Table 1), イエ バエでは点灯するライトトラップの台数にかかわらず, 総 捕獲数に有意な差は認められなかった（ $p>0.05$, Tukeyの HSD 検定, Table 2). 一方, ノミバエは 2 台以上の点灯と 1 台のみの点灯との間で総捕獲数が有意に異なることがあっ た（全点灯と $0 \mathrm{~m}$ のみ点灯： $p<0.001$, 全点灯と $1.5 \mathrm{~m}$ のみ点 灯： $p=0.009$, 全点灯と $2.5 \mathrm{~m}$ のみ点灯： $p=0.012,0 \mathrm{~m}$ 以外点 灯と $0 \mathrm{~m}$ のみ点灯： $p<0.001,0 \mathrm{~m}$ 以外点灯と $1.5 \mathrm{~m}$ のみ点灯： $p=0.008,0 \mathrm{~m}$ 以外点灯と $2.5 \mathrm{~m}$ のみ点灯： $p=0.011,0 \mathrm{~m}, 0.5 \mathrm{~m}$ 以 外点灯と $0 \mathrm{~m}$ のみ点灯： $p<0.001,0 \mathrm{~m}, 0.5 \mathrm{~m}$ 以外点灯と $1.5 \mathrm{~m}$ のみ点灯： $p=0.018,0 \mathrm{~m}, 0.5 \mathrm{~m}$ 以外点灯と $2.5 \mathrm{~m}$ のみ点灯： $p=0.025,0 \mathrm{~m}, 0.5 \mathrm{~m}, 1.0 \mathrm{~m}$ 以外点灯と $0 \mathrm{~m}$ のみ点灯： $p=0.003$, $0 \mathrm{~m}, 0.5 \mathrm{~m}, 1.0 \mathrm{~m}, 1.5$ 以外点灯と $0 \mathrm{~m}$ のみ点灯： $p<0.001,0 \mathrm{~m}$,
$0.5 \mathrm{~m}, 1.0 \mathrm{~m}, 1.5 \mathrm{~m}$ 以外点灯と $1.5 \mathrm{~m}$ のみ点灯： $p=0.022,0 \mathrm{~m}$, $0.5 \mathrm{~m}, 1.0 \mathrm{~m}, 1.5 \mathrm{~m}$ 以外点灯と $2.5 \mathrm{~m}$ のみ点灯： $p=0.030$, Tukey のHSD検定)．全ライトトラップが点灯しているときと同様 に, 最も下で点灯しているライトトラップの対面で紫外線強 度が最大になることはなく, 各高さのイエバエまたはノミバ 工の平均捕獲数と紫外線強度（最大值）との間には有意な相 関関係はなかった（0m以外点灯，イエバエ： $n=5, r=0.291$, $p=0.635$, ノミバエ： $n=5, r=-0.727, p=0.164,0 \mathrm{~m}, 0.5 \mathrm{~m}$ 以 外点灯, イエバエ： $n=4, r=0.267, p=0733$, ノミバエ： $n=4$, $r=-0.847, p=0.153,0 \mathrm{~m}, 0.5 \mathrm{~m}$, および $1.0 \mathrm{~m}$ 以外点灯, イ工 バエ： $n=3, r=0.085, p=0.946$, ノミバエ： $n=3, r=-0.561$, $p=0.621$, Pearsonの相関係数，ただし， $n=2$ 以下となる $2.0 \mathrm{~m}$ 以上の点灯は解析していない). 1台のみが点灯する条件で は，点灯しているライトトラップの対面の紫外線強度が最大 值であった（Table 1).

\section{考察}

室内でライトトラップを $0.5 \mathrm{~m}$ 間隔で $0 \mathrm{~m}$ から $2.5 \mathrm{~m}$ まで垂 直方向に並べて同時点灯させると，イエバエは最も下のライ 
トトラップに捕獲数が偏ることが明らかとなった. 複数のラ イトトラップを用いた誘引試験では，相互の干渉が指摘され ることがある (Hartstack et al., 1971)．本研究では垂直方向に ライトトラップを近接させても捕獲される高さに偏りが生じ たことから，イエバエは明確な高さ選好性を有することが明 らかとなった. イエバエが最も下のライトトラップに捕獲さ れる傾向は，下から順に消灯した試験でも同じであった。 方，ライトトラップを1台のみ点灯して高さを変更した場合 は高さごとに捕獲数に有意な差は認められなかった。これら のことから，屋内においてライトトラップの高さの選好性を 調べるためには垂直方向に同時に複数台を稼動させた本試験 方法は有効と考えられる.

イエバエの発生場所は屋外のほうが多いが, 成虫は屋内侵 入性があり, 好んで屋内に入ってくる（篠永, 1995). 屋内 におけるイエバエの飛翔行動については古くから研究がある が, 高さとの関係については夜間に天井で休息することがよ く知られている（緒方，1959; 大利ら，1960）。本試験の部屋 のサイズは Snell（2002）と同程度であり，イエバエは放虫地 点からライトトラップまで十分に達することができる距離と 考えられる．このような条件下でイエバエの高さの選好性が 明確となったが，全点灯および下から順に消灯した場合のい ずれにおいても，紫外線強度は最も下で最大值になることは なかったため，イエバエの高さ選好性は紫外線強度では説明 できない，室内におけるライトトラップを用いた飛翔性昆虫 類のモニタリングは, 発生箇所から最も近いライトトラップ に誘引されるという仮定で実施されている（江藤ら，1999）. 最も下に位置するライトトラップは放虫地点から最も近い が，これでも十分に説明できない.

一方，ノミバエは統計的に有意ではないものの, 全点灯で は最も上 $(2.5 \mathrm{~m})$ と最も下のライトトラップに捕獲数が偏 る傾向があり, 下から順に $1.5 \mathrm{~m}$ まで消灯していくと最も上 に捕獲数が有意に多かった.ノミバ工類は建物内でもしばし ば発生するが, 建物内の飛翔行動についてはほとんど研究さ れていない. 本試験と同様に20ワットのブラックライト（蛍 光管）を1本付設した粘着式ライトトラップでは，才オキモ ンノミバエMegaselia spiracularis Schmitzを少なくとも $20 \mathrm{~m}$ の 距離から誘引できることが報告されており（江藤ら，1999）, 本試験を行った部屋程度の大きさならば十分に誘引できる距 離であると推察される. しかしながら，ノミバエについても 高さ選好性と紫外線強度との関係はなかった。

建築物においてハエ・コバエ類は重要な害虫であり, 維持 管理マニュアル（建築物環境衛生維持管理要領等検討委員 会, 2008）では，ハエ・コバエ類の目標水準も設けられてい る. 目標水準に記された捕獲数あるいは指数の状況を確認す るために用いられるライトトラップは, 種によって捕獲効率 のよい設置高が異なることが本研究から明らかとなった．本 試験では八工類としてイエバエ，コバエ類としてノミバエを 使用したが, 実験動物として入手可能な他種のハエ・コバエ 類についても同様に試験することによって，それぞれのライ トトラップの高さの選好性が明らかになると考えられる。一 方, 通常のモニタリング調査においては垂直方向に複数のト ラップを設置することはなく，1台のみが設置されている場 合が多い. 本試験において1台のみを点灯した結果から, イ エバエ，ノミバエともに1台のみならば，そこへ集中的に捕 獲されることが明らかとなった。 このことから, 通常のモニ
タリング調査において，ライトトラップはメンテナンスや安 全性などの運用や管理に配慮して高さを設定できると思われ る. 一方, 複数台点灯した結果からは高さに捕獲数の違いが 認められるため, 複数のトラップを用いて施設内のハエの分 布を調べるような目的では，捕獲効率を均一にするためにう イトトラップの高さを床から統一する必要がある.

誘虫ランプの点灯数を変えてイエバエ成虫の捕獲数を比較 した試験では, 総ワット数が多いほど捕獲数が増加すること から，光強度に依存的であることが報告されている（Snell, 2002). しかしながら, 本研究では, 複数のライトトラップ を点灯してもイエバエの総捕獲数の増加は認められなかっ た. 本試験の部屋のサイズはSnell (2002) と同程度であるが, この程度の部屋の大きさではライトトラップの光強度が捕獲 数に必ずしも影響しないことが示唆された. 少なくとも, イ エバエについては, 本研究で用いた部屋の大きさでは $1 つ の$ ライトトラップで十分に捕獲できることが明らかとなった. 一方, ノミバエについては光強度と捕獲数との関係が報告さ れていないが, 本研究では複数台のライトトラップの設置で 捕獲数が有意に多くなることがあった．これらの結果から， 本研究で用いた部屋の大きさでは, 複数のライトトラップを 用いることで採集効率が上がることが示唆された。本研究か ら，ノミバエはイエバエと比べてライトトラップでの捕集効 率が低いと考えられ，採集効率の向上が期待できる本知見は 今後のノミバエの効率的・効果的な調查の基礎情報になると 思われる.

屋内は屋外とは異なり, ライトトラップの光源が床, 壁, 天井に反射しやすい. 屋内でしばしば問題になる貯穀害虫の タバコシバンムシにおいては直接光よりも反射光を好むこと が報告されており（宮竹，大前，2014），室内ならではの環 境が捕獲数に影響を及ぼしている可能性がある. 今後, 検討 が必要である.

\section{謝辞}

本試験を遂行するにあたり，ご協力を頂いたイカリ消毒株 式会社技術研究所の各位に厚く御礼申し上げます.

\section{文献}

江藤 諮, 田近五郎， 中村寛志. 1999. 食品工場におけるラ イトトラップを用いた飛翔性昆虫のモニタリング手法に関 する研究. 環動昆, 10: 1-10.

Frost, S. W. 1958. Insects attracted to light traps placed at different heights. J. Econ. Entomol., 51: 550-551.

Hartstack, A. W. Jr., Hollingsworth, J. P., Ridgway, R. L. and Hunt, H. H. 1971. Determination of trap spacing required to control an insect population. J. Econ. Entomol., 64: 1090-1100.

平尾素一. 2008. IPM実施モデル. 建築物におけるIPM実践 ハンドブック（田中生男編集代表）, pp. 59-107. 中央法規, 東京.

川上裕司, 杉山真紀子. 2009. 博物館・美術館の生物学一力 ビ・害虫対策のためのIPMの実践. 174 pp., 雄山閣, 東 京.

建築物環境衛生維持管理要領等検討委員会.2008. 建築物にお ける維持管理マニュアル. [accessed May 20, 2020]. Available from: https://www.mhlw.go.jp/bunya/kenkou/seikatsu-eisei09/ pdf/03a.pdf

厚生労働省. 2008. 建築物環境衛生管理基準について. [accessed May 20, 2020]. https://www.mhlw.go.jp/bunya/kenkou/ seikatsu-eisei10/ 
三井英三. 1990. 食品工業と害虫. 240 pp., 光琳，東京。

宮竹貴久，大前雄介. 2014. タバコシバンムシ Lasioderma serricorneは直射ではなく反射UV-LEDによく誘引される. 日本応用動物昆虫学会誌, 58: 133-135.

緒方一喜. 1959. 住家内外で冬季にみられたイエバエ及びヒ メイエバエの行動について．衛生動物，10:251-257.

尾野一雄，塩田智哉，江藤 諮，佐藤邦裕. 2016. 異物混入 対策. 異物混入を防ぐ (佐藤邦裕, 江藤 諮監修), pp 26-87. 日本食品衛生協会，東京.

大利茂久，下釜 勝，和田義人. 1960. イエバエの家屋内に おける夜間静止場所について。長崎大学風土病紀要，2: 154-159.

篠永 哲. 1995. 八工．家屋害虫事典（日本家屋害虫学会 編)，pp. 178-193. 井上書院，東京.

Snell, E. 2002. Factors affecting laboratory procedures for evaluating efficacy of insect light traps for house flies. In: Proceedings of the 4th International Conference on Urban Pests (ed. Jones, S.C. Zhai, J. and Robinson, W.H.), pp.187-198, Pocohontas Press, Virginia.

田中生男. 2008. 建築物におけるねずみ・害虫等の維持管理 の進め方. 建築物における IPM実践ハンドブック（田中生 男編集代表)，pp.9-57. 中央法規，東京.

谷川力, 富岡康浩, 池尻幸雄, 白井英男, 吉浪 誠. 2007. 写真で見る有害生物防除事典. 197 pp., オーム社, 東京. 